CUADERNOS DE ESTUDIOS GALLEGOS, LXII Núm. 128 (enero-diciembre 2015), págs. 355-387

ISSN: $0210-847 \mathrm{X}$

DOI: 10.3989/ceg.2015.128.12

\title{
TODA HISTORIA LLEVA IMPLÍCITA UNA ANTROPOLOGÍA. UNA INDAGACIÓN EN LA HISTORIA DEL PENSAMIENTO OCCIDENTAL*
}

\author{
José María Cardesín Díaz \\ Universidade da Coruña
}

\footnotetext{
* Este artículo se ha beneficiado del apoyo de la Red Nuevos Enfoques del Análisis Territorial: Implicaciones Sociales, Económicas y Formativas (NEDAT) (R2014/018). La Red cuenta con financiación de la Consellería de Cultura, Educación e Ordenación Universitaria, dentro del Programa para la Consolidación y Estruturación de Unidades de Investigación Competitivas del Sistema Universitario de Galicia, Modalidad Redes.
} 
TODA HISTORIA LLEVA IMPLÍCITA UNA ANTROPOLOGÍA. UNA INDAGACIÓN EN LA HISTORIA DEL PENSAMIENTO OCCIDENTAL

\section{ResUMEN}

Por qué constituyen antropología e historia dos disciplinas separadas, de cuando data esa separación, cual es el grado de permeabilidad que se registra entre ambas? Estas son las preguntas que intentaré responder en este artículo. Centraré mi argumentación en tres cuestiones. La primera, que dado que la antropología es un "logos" acerca del "anthropos", podemos argumentar que no puede existir historia carente de antropología: es lo que intentaremos mostrar en un breve recorrido por la historia del pensamiento occidental, desde la Grecia Clásica a la Ilustración. A continuación analizaremos como antropología e historia se enfrentaron al problema del cambio social en el siglo XIX, se diferenciaron como disciplinas académicas a finales de siglo y parecieron "cortar amarras" en el periodo de entreguerras, en las décadas de 1920 y 1930. Pero, aún en esas difíciles circunstancias, algún tipo de comunicación siempre se mantuvo entre ambas. De los dos primeros puntos se deduce un tercero: que es importante llegar a entender la antropología que subyace, siempre, en los escritos de los grandes historiadores que han sido nuestros maestros. Buscaremos ejemplos en sendas tradiciones historiográficas: la francesa Escuela de los Annales y la historiografía británica.

Palabras Clave: Historiografía, antropología, interdisciplinariedad, naturaleza humana, acción colectiva

\section{TODA HISTORIA IMPLICA UNHA ANTROPOLOXÍA. UNHA INDAGACIÓN NA HISTORIA DO PENSAMENTO OCCIDENTAL}

\section{Resumo}

Por qué constitúen antropoloxía e historia dúas disciplinas separadas, de cando data esa separación, cal é o grao de permeabilidade que se rexistra entre ambas as dúas? Estas son as preguntas as que intentarei buscar resposta neste artigo. Centrarei a miña argumentación en tres cuestións. A primeira, que dado que a antropoloxía é un "logos" acerca do "anthropos", podemos argumentar que non pode existir unha historia carente de antropoloxía: é o que intentaremos amosar nun breve percorrido pola historia do pensamento occidental, dende a Grecia Clásica á Ilustración. A continuación analizaremos como antropoloxía e historia enfrontáronse ao problema do cambio social no século XIX, diferenciáronse como disciplinas académicas a finais de século e pareceron "cortar amarras" no período de entreguerras, nas décadas de 1920 e 1930. Mais, aínda nesas difíciles circunstancias, algún tipo de comunicación sempre se mantivo entre elas. Dos primeiros puntos dedúcese un terceiro: que resulta importante chegar a entender a antropoloxía que está agachada, sempre, nos escritos daqueles grandes historiadores que teñen sido os nosos mestres. Buscaremos exemplos en sendas tradicións historiográficas: a francesa Escola dos Annales e a historiografía británica.

Palabras Clave: Historiografía, antropoloxía, interdisciplinariedade, natureza humana, acción colectiva

\section{EVERY HISTORY IMPLIES AN ANTHROPOLOGY. A STUDY INTO THE HISTORY OF WESTERN THOUGHT}

\section{AbSTRACT}

Why do anthropology and history seem to be two completely autonomous disciplines? When did they split up? Do they keep talking? -at least in order to raise their common offspring... Three will be my points. Firstly, as anthropology is a "logos" about "anthropos", history is not possible without some anthropology. I think that a short tour through the history of Western thought, from Ancient Greece to Enlightenment, will show it clearly. Secondly, we will analyze how history and anthropology approached the issue of social change in the XIXth century, how they became autonomous academic disciplines by the end of the century, and cut off in the interwar period, by the 1920s and 1930s. But "underground" contact was kept, waiting for more favourable circumstances. Third, I think that historians should try to understand that anthropology that always underlies on the writings of those who taught us our job. We will look for examples in two historiographical traditions: the French "Ecole des Annales" and the British "Group of Cambridge" of the 1950s.

KEY WORDS: Historiography, anthropology, interdisciplinariety, human nature, collective action 
Recibido/Received: 14/04/2015

Aceptado/Accepted: 03/07/2015

Yi, por casualidad, un antropólogo se encuentra con un historiador, rezaba el provocador título de un ensayo de Marcel Detienne ${ }^{1}$. Porque, en efecto, $\bigcup$ antropología e historia parecían, en la Francia del cambio de milenio, dos disciplinas completamente independientes, que semejaban comportar sendas metodologías y objetos de estudio radicalmente distintos. Un panorama no muy diferente del que por entonces mostraba España, a no ser por el hecho de que la antropología estaba menos consolidada en nuestro país.

Pasados quince años, son ya muchos los que reconocen el interés del diálogo interdisciplinar, aunque esta opinión deje de ser mayoritaria cuando se plantea la posibilidad de practicarlo antes de llegar al terreno de los masters. Aún entonces cabría preguntarse: qué objeto podría tener intercambiar metodologías, conceptos, campos de estudio - "terrains"- entre disciplinas que se presumen de naturaleza tan diferente?

En 1997 Areas, una publicación periódica de historia que se subtitula como "Revista de Ciencias Sociales" nos encargó coordinar un número especial sobre el estado de la antropología en España que estaba -y esa era la novedad-dirigido a los historiadores. El monográfico se publicó dos años más tarde bajo el título de Antropología Hoy: Teorías, técnicas y tácticas ${ }^{2}$. Sus contenidos tocaban algunas de las principales líneas de investigación de la disciplina: antropología jurídica, ecológica, urbana, del género, culturas del trabajo, migraciones, identidades. También se recogían algunos textos consagrados a la reflexión teórica y metodológica. Apenas uno de estos últimos se interrogaba de manera expresa acerca de por qué constituían antropología e historia dos disciplinas separadas, de cuando databa esa separación y del grado de permeabilidad entre ambas que se pudiera haber venido registrando a pesar de ello ${ }^{3}$.

\footnotetext{
1 Marcel Detienne, "Si, por casualidad, un antropólogo se encuentra con un historiador", en Comparar lo incomparable. Alegato a favor de una ciencia histórica comparada, Barcelona, Península, 2001, págs. 17-41.

2 Número monográfico “Antropología Hoy. Teorías, técnicas, tácticas”, Areas. Revista de Ciencias Sociales, 19 (1999), 286 págs.

3 Jean Luc JamARD, "Pueden equivocarse los antropólogos? Antropología, ciencias e historia", Areas. Revista de Ciencias Sociales, 19 (1999), págs. 256-286.
} 
Este será el cometido del presente artículo. Centraré mi argumentación en tres cuestiones. La primera, que dado que la antropología es un "logos" acerca del "anthropos", podemos argumentar con seguridad que no puede existir historia carente de antropología: es lo que intentaremos mostrar en un breve recorrido por la historia del pensamiento occidental, desde la Grecia Clásica a la Ilustración. A continuación analizaremos como antropología e historia se enfrentaron al problema del cambio social en el siglo XIX, se diferenciaron como disciplinas académicas a finales de siglo y parecieron "cortar amarras" en el periodo de entreguerras, en las décadas de 1920 y 1930. Pero, aún en esas difíciles circunstancias, algún tipo de comunicación siempre se mantuvo entre ambas. De los dos primeros puntos se deduce un tercero: que es importante llegar a entender la antropología que subyace, siempre, en los escritos de los grandes historiadores que han sido nuestros maestros. Buscaremos sendos ejemplos en las dos grandes tradiciones historiográficas de las que se alimentó mi generación: la francesa Escuela de los Annales y la historiografía británica.

\section{De la Grecia clásica al "COntrato social"}

La antropología es un "logos acerca del anthropos", una teoría racional acerca de la naturaleza humana y de la acción social. Y una teoría así está presente en cualquier reflexión histórica, sea o no consciente de ello el historiador. En el mundo antiguo no existía la actual división entre disciplinas como la historia, la sociología o la antropología. Pero todo relato que se redactara entonces, y que ahora coincidimos en reconocer como "histórico", llevaba implícita una antropología.

La idea tan cara a la civilización occidental del carácter perverso, egoísta del ser humano, que parece abocado a una búsqueda individualista de riqueza y poder, no es ni mucho menos universal. Para el confucianismo, por ejemplo, el ser humano es por naturaleza bondadoso, y algo similar se podría predicar de otras culturas. Pero la peculiaridad occidental tiene una larga genealogía que arranca al menos de la Grecia Clásica ${ }^{4}$.

El texto fundacional para nuestro gremio es, como no, la Historia de la Guerra del Peloponeso de Tucídides 5 . Esta contienda "fratricida" que se prolongó durante décadas proporcionó al padre de los historiadores numerosas oportunidades para disertar sobre los efectos de la oposición latente entre, de un lado, el "demos" y del otro oligarcas o "aristoi", rivalidad consustancial a las polis de los siglos V y IV a.C. Un antagonismo que venía a dar resultados letales cuando se combinaba

\footnotetext{
${ }^{4}$ Marshall SAHLINS, The Western Illusion of Human Nature. With reflections on the long history of hierarchy, equality, and the sublimation of anarchy in the West, and comparative notes on other conceptions of the human condition, Chicago, Prickly Paradigm Press, 2008.

5 Tucidides, Historia de la Guerra del Peloponeso, Madrid, Gredos, 1992.
} 
con situaciones de guerra en que cada facción buscaba el apoyo militar de Atenas o Esparta. El fragmento clásico es el que narra las atrocidades en que acabó desembocando la guerra civil entre los oligarcas y la fracción mayoritaria del demos en Corcyra (la actual Corfú), un texto que siglos más tarde fascinaría a Hobbes. Pero también interesaría y mucho, al mismo autor, la disgregación del orden social que acompañó a la "peste" - probablemente una epidemia de fiebres tifoideas- que asoló Atenas en el año 427 a.C.

Cuales son las condiciones para que la conducta social colectiva se desarrolle de manera, si no armoniosa, al menos dentro de unos límites razonables? Y por qué las personas se portan mal, a veces terriblemente mal? Como a tantas otras preguntas, Platón y Aristóteles vinieron a exponer las dos soluciones más socorridas desde entonces.

Aristóteles concibe a los seres humanos como animales dotados de una naturaleza racional y política ${ }^{6}$. Es decir los humanos por antonomasia, los helenos, que por naturaleza se diferencian de los bárbaros. Y la misma creación de la polis, de la vida política, está orientada a proporcionarles el medio propicio para dar rienda suelta... a su naturaleza. Aristóteles no ignora -todo lo contrario- las tensiones que enfrentan a ricos y pobres: para contenerlas cuenta con la "diké", la justicia. Y al tiempo formula como solución alternativa para garantizarla el recurso a dos regímenes políticos, monarquía y república: la justicia puede derivar tanto del miedo al monarca como de la "isonomía" entre fuerzas sociales que se controlan mutuamente.

Platón por su parte va a desplazar la discusión hacia otros derroteros, a una oposición casi podríamos decir -anacronicamente- entre naturaleza y cultura: o más bien a la alternativa, introducida por los sofistas, entre "physis" (que podríamos traducir por naturaleza) y "nomos" (algo así como convención). Para los sofistas lo social es variable, contingente, y por lo tanto lo que los humanos llaman virtud es simplemente convención. Platón reacciona airadamente contra esta posibilidad: para él la virtud es conocimiento, no convención ${ }^{7}$. Aquellos seres humanos por excelencia-los helenos-, cuando actúan individual o colectivamente, tienden al bien, a buscar la vida buena, la felicidad. El problema es la ignorancia que les lleva a equivocarse, a caer en la "hybris" o desmesura. El antídoto es la educación entendida como gimnasia, una disciplina capaz de adiestrar al cuerpo para subordinarlo al correcto desempeño de ciertas funciones. Y de ahí que los "guardianes" que propone para gobernar la República se caractericen por el autocontrol, tal como evidencia el "mito del auriga": la razón como cochero capaz de conducir a dos corceles con impulsos contradictorios, el caballo blanco de

\footnotetext{
6 Aristoteles, La Política, Madrid, Espasa Calpe, 1995.

7 Platón, La República, en Obras completas, Madrid, Aguilar, 1993.
} 
las pasiones, el negro de los apetitos ${ }^{8}$. Aquí aparece por primera vez esbozada, reformulando las ideas de los pitagóricos, aquella dualidad latente entre alma y cuerpo que el propio Platón llegará a concebir como "cárcel del alma".

Esta es la antropología y sociología implícita en la Historia de la Guerra del Peloponeso o en la Anábasis de Jenofonte ${ }^{9}$ : la moraleja de la historia de la ruina de Atenas narrada por Tucídides, o de la huída exitosa de los diez mil compañeros de Jenofonte viene a confirmar la antropología de la que parten ambos autores.

La filosofía helenística va a desplazar el ámbito de reflexión. La polis independiente ha quedado reducida a anacronismo, desplazada por un pequeño número de monarquías gobernadas por sus correspondientes déspotas. Cínicos, estoicos y epicúreos trasladan su mirada al individuo. Y algo similar va a producirse en la Antigua Roma a partir del Alto Imperio, donde desde el universalismo estoico se formula el concepto de "cosmópolis". La ideología imperial se colorea de filosofías "religiosas", como el neoplatonismo y el neopitagorismo. Pero estas corrientes aportan una solución muy limitada para abordar el problema del "mal social", el reto de cómo controlar a las multitudes, a esa plebe enfurecida de la que ya hablaba el historiador Polibio:

la superstición mantiene unido al pueblo romano [...] Pero como toda multitud es voluble, cargada de deseos ilícitos, de pasiones irracionales y de iras violentas, tiene que ser contenida por terrores invisibles y fastos semejantes ${ }^{10}$.

La solución la va a proporcionar el cristianismo, y no precisamente el que se desprende de las predicaciones de Jesús de Nazaret, sino aquel otro cuyos fundamentos comienza a poner una generación más tarde Pablo de Tarso. Con este se registra un cambio abrupto en la concepción del ser humano y en la justificación del orden político, auténtica clave de la construcción del pensamiento político occidental a partir de entonces. En su Carta a los Romanos Pablo introduce una idea rupturista en términos antropológicos: la naturaleza humana es pecaminosa, el mal no es ya accidente o error, sino rasgo consustancial al ser humano.

me deleito en la Ley de Dios según el hombre interior, pero siento otra ley en mis miembros que repugna a la ley de mi mente y me encadena a la ley del pecado ${ }^{11}$.

\footnotetext{
8 Platón, Fedro, en Obras completas, Madrid, Aguilar, 1993.

9 Jenofonte, Anábasis, Madrid, Gredos, 1991 (ed. original de c.368 a.C.).

${ }^{10}$ Polibio de Megalopolis, Historia de Roma, Madrid, Alianza, 2008 (ed. original de s.II a.C.).

${ }^{11}$ Rom 7, 22-23.
} 
Sus seguidores van a llevar a cabo una labor especialmente compleja para combinar la filosofía helenística y la Torah judía. Al Talmud judaico le resultaba extraña la dualidad cuerpo-alma y por ello carecía de prevenciones contra los placeres. En los ambientes helenizados de Alejandría, donde imperaba el platonismo neopitagórico, Filón retoma el concepto de pecado original de la Torah, helenizando a la primera mujer -Eva-según el modelo de la Helena de Troya, "perdición de los hombres". La razón ya no se concibe a la manera de Platon como un auriga, sino como el capitán de un barco que debe doblegar a la chusma amotinada de las pasiones del alma y los apetitos de la carne. Y por primera vez, el sufrimiento humano y la automortificación de la carne adquieren razón de $\operatorname{ser}^{12}$.

En consecuencia, la nueva ética política cristiana que se sistematiza a partir de Pablo, ya no se justifica en la búsqueda de la felicidad. Dado que los seres humanos pasan a considerarse por naturaleza malos -lobos con piel de hombre-, la función del gobernante pasa a ser la de mantener a raya -a garrotazos- a un rebaño de lobos, para que no se agredan unos a otros. Y correlativamente la doctrina de la autoridad se reformula de manera radical: la que corresponde al gobernante ya no deriva del pueblo, sino de Dios.

Todos han de estar sometidos a las autoridades superiores, pues no hay autoridad sino bajo Dios; y las que hay por Dios han sido establecidas, de suerte que quien resiste a la autoridad resiste a la disposición de Dios, y los que la resisten se atraen sobre si la condenación ${ }^{13}$.

Un Dios que quiere que haya gobernantes, pero que no se compromete con lo que estos puedan hacer con las atribuciones que reciben. Aún más, el mal gobernante puede ser concebido como castigo por los pecados de los hombres. Y de ahí que la obligación de obedecer - aún al tirano-no admita en principio excepciones.

Una visión antropológica y una ética política que se imponen como doctrina oficial en el Bajo Imperio conforme lo hace el cristianismo, primero con su oficialización en el Concilio de Nicea (325), más adelante con la prohibición de las demás religiones con el edicto de Teodosio, "el Grande" (384). Y que acaba de sistematizar Agustín de Hipona en los últimos años del Imperio, como legado para la Alta Edad Media, cuando argumenta en La ciudad de Dios que la legitimidad del emperador no es muy distinta a la que posee el líder de una banda de piratas, en cuya boca pone estas palabras:

\footnotetext{
12 Rafael Sanchez Ferlosio, "La música celestial de la verdad”, Le Monde Diplomatique: número de Marzo, 1999, págs. 30-31.

13 Rom 13, 1-7.
} 
porque yo lo hago con un barco me llaman ladrón; y a ti, porque lo haces con una gran escuadra te llaman emperador ${ }^{14}$.

Esta visión antropológica, que invita al príncipe a usar su bastón contra los lobos que se esconden en su rebaño, está presente en textos de interés "etnográfico" como el De correctione rusticorum de Martín de Dumio ${ }^{15}$, pero también en las Crónicas altomedievales, como la Historia de los Francos de Gregorio de Tours $^{16}$. En tanto historiadores, Tucídides o Gregorio de Tours parten de premisas antitéticas: y seleccionan los hechos, los organizan en un relato, dando por sentada cada uno la antropología que es aceptada en sus épocas respectivas.

A grandes rasgos la antropología agustiniana subyace a la historiografía medieval. Sobre todo cuando Tomás de Aquino reorganiza aquella ${ }^{17}$ dentro del aparato conceptual legado por Aristóteles y ahora parcialmente recuperado. No sin registrar contradicciones fundamentales. De un lado, y a diferencia de Aristóteles, el objeto de la vida social, de la vida organizada en ciudades y estados, ya no es satisfacer una naturaleza humana abocada a la "política". Por el contrario, para el Aquinate la vida en sociedades complejas tiene un objetivo meramente funcional, casi diríamos "económico": proporcionar las condiciones mínimas para desarrollar la división del trabajo ${ }^{18}$. Pero de otro lado esa división del trabajo lleva implícita dificultades similares a las que vivieron los griegos para conciliar el interés individual con el colectivo. Y Tomás de Aquino será el último de los grandes pensadores en apostar por la posibilidad de conciliar ambos intereses sin que llegue a primar el individual.

Frente a la apuesta monárquica de Agustín de Hipona o de Tomás de Aquino el segundo principio por el que Aristóteles vería posible asegurar la justicia, el republicano, reaparece en aquellas repúblicas mercantiles italianas de la baja Edad Media, nuevamente sacudidas por las tensiones entre ricos y pobres. Hasta llegar a Maquiavelo, donde la oposición entre plebe y poderosos, bien institucionalizada, es la clave de la libertad y la prosperidad de las repúblicas. Aunque, qué difícil resulta a veces llegar a, y sobre todo mantener, esa correcta institucionalización... ${ }^{19}$

\footnotetext{
${ }^{14}$ Agustín de Hipona, La Ciudad de Dios, México, Porrúa, 1970 (ed. original de c. 426).

${ }^{15}$ Martín de Dumio, De Correctione Rusticorum, A Coruña, Espiral Maior, 1997 (ed. original de c. 575).

${ }^{16}$ Gregorio de Tours, Histoire des Francs, París, Ed. Belles Letres, 1980.

17 Tomás de Aquino, Summa Teologiae, Madrid, Biblioteca de Autores Cristianos, 1917 (ed. original de s.XIII).

${ }^{18}$ Louis Dumont, Ensayos sobre el individualismo. Una perspectiva antropológica sobre la ideología moderna, Madrid, Alianza, 1987.

${ }^{19}$ Nicolás Maquiavelo, El príncipe, Madrid, Alianza 2010 (ed. original de 1531).
} 
Finalmente, al llegar a la edad moderna y en el marco de las dos revoluciones inglesas del siglo XVII, el pesimismo agustiniano y la antropología "optimista" de la Grecia clásica se recuperan en la obra de Thomas Hobbes ${ }^{20}$ y John Locke ${ }^{21}$ respectivamente, que también optan, uno y otro, para poner remedio a los males que comporta la naturaleza humana, por las dos grandes soluciones políticas de Aristóteles, monarquía y república. Pero tanto en los optimistas como en los pesimistas se introduce una nueva idea: el contrato social que viene a suceder a un estado de naturaleza previo.

En Hobbes se reelabora la visión negativa de la naturaleza humana de Pablo de Tarso: "homo homini lupus", el hombre es un lobo para el hombre. Traductor el mismo de la Historia de la Guerra del Peloponeso de Tucídides, Hobbes no duda en recurrir a aquellos ejemplos que citábamos más arriba sobre la guerra civil en Corcyra y la disolución del orden social en la Atenas asolada por la peste, para exhibirlos como muestra de ese estado de naturaleza que se caracteriza por la guerra de todos contra todos.

El pacto que instituye el estado nace del miedo, que lleva a los individuos a renunciar a sus derechos naturales y a investir a ese estado del temor reverencial que antes les inspiraba la religión ${ }^{22}$. Una idea que, de un lado, supone romper con la tradición paulina, dado que a partir de ahora la autoridad ya no proviene de dios: el Estado, cual Leviatán, aparece en la portada del libro empuñando en una mano la espada y en la otra el báculo del obispo. Pero también se aleja Hobbes de manera radical del legado de Aristóteles, para el que la "civitas" permitía a los individuos llevar hasta el último término lo que estaba en su naturaleza, y no romper con ella.

Ya no víctima de la primera revolución inglesa, sino apóstol de la segunda revolución "gloriosa", John Locke le da la vuelta a la relación entre naturaleza y orden político en su Segundo ensayo sobre el gobierno civil. El estado de naturaleza ya no se caracteriza por la guerra, sino por la escasez relativa. La invención del dinero permite obviar el problema del carácter perecedero de los bienes y posibilita que los individuos los acumulen más allá de lo meramente necesario para la subsistencia. Si en el estado de naturaleza el poder de ejecutar la ley natural (lo que la razón determina como correcto) descansaba en manos de cada individuo, ahora la comunidad política permite establecer las garantías a la propiedad a través de la ley positiva del estado. De ahí que al contrato de

\footnotetext{
${ }^{20}$ Thomas HobBes, Leviatán, o La materia, forma y poder de una república, eclesiástica y civil, México, Fondo de Cultura Económica, 1992 (ed. original de 1651).

${ }^{21}$ John Locke, Primer y Segundo Ensayo sobre el Gobierno Civil, Madrid, Espasa-Calpe 1991 (ed. original de 1690).

${ }_{22}$ Carlo Ginzburg, Por reverència terror. Llegir Hobbes avui, Barcelona, Arcadia, 2009.
} 
sociedad que crea una comunidad le siga un "trust de gobierno", donde el poder político se concede como fideicomiso.

Muy pronto la Ilustración verá en la Europa civilizada la manifestación de los beneficios del contrato social, en la versión inglesa de Locke o en la francesa de Rousseau ${ }^{23}$. Mientras, las huellas del estado de naturaleza primigenio del ser humano pasan a buscarse en los pueblos no occidentales que Europa está encontrando en su expansión: los "salvajes", los "primitivos" de Africa y América; las antiguas civilizaciones asiáticas; pero también, y esto es muy importante, el propio pasado europeo. Como bien argumenta Detienne, los eruditos que escribían historia en el siglo XVIII recurrían por igual al ejemplo de los antiguos griegos y de los iroqueses de las colonias americanas, cuando se trataba de interrogarse sobre el pasado de las propias sociedades europeas ${ }^{24}$. Nada permitía hablar aún de disciplinas diferentes para estudiar a occidentales y no-occidentales, y estamos muy lejos de la famosa formulación de Hegel, en la que vendrá a ubicar a los pueblos no europeos fuera de la corriente de la historia ${ }^{25}$.

\section{De la Ilustración AL PARAdigma EVOLUCIONISTA}

La Ilustración popularizó en el saber letrado la hipótesis de que la acción de los seres humanos guiados por la razón genera movimiento histórico positivo, es decir "progreso". Los utilitaristas ingleses como Hume ${ }^{26}$, añadieron un matiz: la satisfacción del interés individual como criterio de racionalidad. Apenas unos años antes Mandeville había formulado su polémico principio: "de vicios privados, virtudes publicas" 27 . La naturaleza egoísta del ser humano, de todos los humanos, se convertía en el principio que aseguraba la prosperidad colectiva, en vez de ser signo de la naturaleza malvada del hombre ${ }^{28}$.

La economía política inglesa combinó el principio utilitarista con el concepto de "cálculo económico", para llegar a una conclusión más arriesgada: el cálculo económico racional guiado por el interés conduce al progreso humano. De esta forma Adam Smith, elaborando la hipótesis del fisiócrata Turgot ${ }^{29}$, pudo llegar a

\footnotetext{
23 Jean Jacques Rousseau, El contrato social, Madrid, Espasa-Calpe, 1980 (ed. original de 1762).

${ }^{24}$ Marcel DetienNe, "Si, por casualidad, un antropólogo...".

${ }^{25}$ G.W. Friedrich Hegel, Lecciones sobre la filosofia de la historia universal, Madrid, Alianza, 1994 (ed. original de c. 1830).

${ }^{26}$ David Hume, A Treatise of Human Nature, Oxford, Clarendon Press, 1978 (ed. original de 1738).

27 Bernard Mandeville, La fábula de las abejas. Los vicios privados hacen la prosperidad pública, Madrid, Fondo de Cultura Económica, 2004 (ed. original de 1713).

${ }^{28}$ Louis Dumont, Homo aequalis. Génesis y apogeo de la ideología económica, Madrid, Taurus, 1982.

${ }^{29}$ A.R. TuRgot, Discursos sobre el progreso humano, Madrid, Tecnos, 1991 (ed. original de 1750).
} 
distinguir cuatro estadios en la evolución de las sociedades humanas, conforme sus miembros eran capaces de orientar sus actividades productivas según criterios de racionalidad más perfeccionados ${ }^{30}$.

En cualquier caso, quienes asistían a los inicios de la revolución industrial inglesa podían encontrar en su entorno evidencia empírica que parecía corroborar esas hipótesis evolucionistas: las innovaciones tecnológicas generaban un aumento espectacular de la productividad. Ahora bien, esta misma revolución industrial sumía a una parte importante de la población en la pobreza y generaba dislocaciones sociales, políticas y culturales que parecían amenazar con destruir el edificio social. De esta forma, el optimismo inicial de Smith vino a ser reemplazado por el pesimismo de Malthus ${ }^{31}$ y consecuentemente de Ricardo ${ }^{32}$ : la concurrencia de los seres humanos guiados por el interés, conduce al progreso económico, pero también al desastre social.

Esta visión pesimista de un progreso económico lastrado por repercusiones sociales negativas no va a ser superada hasta mediados del S. XIX: cuando en ámbitos tan diversos como la biología y la naciente sociología, Spencer ${ }^{33}$ y acto seguido Darwin ${ }^{34}$, realicen una relectura de Malthus, identificando "progreso" con "aumento de la complejidad". Para Darwin, la lucha de los individuos por obtener mejores condiciones de supervivencia conduce a largo plazo al "progreso evolutivo": al perfeccionamiento de la especie a través del desarrollo de formas orgánicas más complejas. Para Spencer la concurrencia de seres humanos que luchan por mejorar sus condiciones de vida puede producir perturbaciones sociales, pero a largo plazo genera formas de integración social más complejas y perfeccionadas: es decir, "progreso social".

A partir de Spencer el enfoque evolucionista adquiere una posición hegemónica dentro de la teoría social, y la ecuación cambio-evolución-progreso social se convierte en constante en la obra de los principales autores ${ }^{35}$. Algunos de ellos, a fin de mejor entender la diversidad, van a introducir dicotomías que nos recuerdan a los tipos ideales weberianos. Piénsese en el paso del "status" al "contrato"

\footnotetext{
${ }^{30}$ Adam Smith, Lectures on Jurisprudence, Oxford University Press, 1978 (ed. original de 1763).

${ }^{31}$ Thomas Malthus, Ensayo sobre el principio de la población, México, Fondo de Cultura Económica, 1951 (ed. original de 1798).

${ }^{32}$ David Ricardo, Principios de economía política y tributación, Madrid, Pirámide, 2003 (ed. original de 1817).

${ }^{33}$ Herbert Spencer, Principios de sociología, Madrid, Revista de Occidente, 1947 (ed. original de 1876).

${ }^{34}$ Charles Darwin, The Descent of Man and Selection in Relation to Sex, Londres, Murray, 1871.

${ }^{35}$ Colin Wright Mills, La imaginación sociológica, México, Fondo de Cultura Económica, 1961, pág. 166.
} 
en Henry S. Maine (1861) $)^{36}$ y más tarde en Max Weber (1902) ${ }^{37}$; el tránsito de la "comunidad" a la "sociedad" en Ferdinand Tönnies $(1887)^{38}$; y la oposición entre los principios de "solidaridad mecánica” y "solidaridad orgánica” en Emile Durkheim (1902) $)^{39}$, que está en la base de la moderna dicotomía "sociedad tradicional" vs. "sociedad moderna".

Casi todas estas dicotomías comparten un conjunto de características comunes. Son modelos de equilibrio, que priman el concepto de "estructura" frente al de "proceso". El movimiento histórico se introduce en estos modelos como transición entre dos estructuras, el pasado o "tradición" y la "modernidad", que es tanto presente como proyecto de futuro. Finalmente el cambio adquiere un carácter catastrófico: caracterizándose como "crisis", por aquellos autores que lo contemplan como momento creativo, o como "destrucción” o "descomposición”, cuando es visto desde un punto de vista negativo.

Estas dicotomías servían para pensar las diferencias que exhibían diversas formaciones sociales en el espacio (entre lo rural y lo urbano, entre Occidente y la periferia sujeta al expolio colonial), pero también servían para teorizar el paso del tiempo (lo que fue antes la ciudad o el conjunto de Occidente, lo que vendría a ser en el futuro el mundo rural o la periferia). Estos modelos, elaborados por sociólogos, fueron incorporados por los historiadores, que se encontraron con un problema a la hora de hacerlos operativos: ¿cómo introducir el movimiento histórico en un esquema de naturaleza estática? El modelo marxista de la "revolución burguesa" vino a proporcionar una solución aparente: el cambio histórico se introducía como "crisis", como transición brusca entre dos estructuras estáticas: feudal, de antiguo régimen o precapitalista la primera, capitalista o propia del estado liberal la segunda ${ }^{40}$.

Estos estudios, que ponen la base de la tradición funcionalista, sufren de una dificultad mas general de la ciencia social para pensar la historia. Las principales corrientes de pensamiento de finales del siglo XIX parecen abordar el movimiento histórico como una sucesión de estadios: los principales procesos del cambio social a gran escala llevarían a las sociedades a atravesar una serie de estadios, que conllevan un progreso creciente, a través de la adopción de formas

\footnotetext{
${ }^{36}$ Henry S. Marne, Ancient Law, Londres, The World's Classics, 1961 (ed. original de 1859).

${ }^{37}$ Max WeBer, "Capitalismo y sociedad rural en Alemania", Ensayos de sociología contemporánea, II, Barcelona, Planeta, 1985, págs. 133-162 (ed. original de 1906).

${ }^{38}$ Ferdinand Tonnies, Comunidad y asociación. El comunismo y el socialismo como formas de vida social, Barcelona, Península, 1979 (ed. original de 1887).

39 Emile Durkherm, La división del trabajo social, Barcelona, Planeta, 1985 (ed. original de 1902).

40 José María CARDESIN, "Miseria de la Teoría... de la Modernización: una revisión de algunos estudios sociológicos sobre el mundo rural contemporáneo", Agricultura y Sociedad, 84 (1997), págs. 141164.
} 
de integración crecientemente complejas. Tampoco escapaban de este modelo de estadios las obras de carácter más procesual, como las inspiradas en el marxismo. El propio Marx había puesto las bases, al definir una serie jerárquica de "modos de producción" y explicar la transición de un "modo" a otro sobre la contradicción entre progreso de las fuerzas productivas y mantenimiento de las relaciones de producción: la "crisis" entendida como momento creativo, dinamizada por la "lucha de clases", que abre el camino para nuevas relaciones de producción, el progreso social ${ }^{41}$.

El planteamiento resultaba problemático por dos tipos de cuestiones. En primer lugar es intrínsecamente contradictorio en términos de lógica formal: como bien argumenta Jamard ${ }^{42}$, la idea de un proceso que mediara el tránsito entre dos estructuras es algo así como la cuadratura del círculo, como hacer compatible a Heráclito ("todo cambia, nada permanece") con Parménides ("el ser es, el no ser no es). Y además porque estas dicotomías son el resultado de un debate entre intelectuales, no una transposición de lo que se pudiera desprender de la evidencia empírica. Y lo que sugiere el trabajo de Alfonso Ortí y Cristóbal Gómez ${ }^{43}$ es que por ejemplo la dicotomía status-contrato de Max Weber supone el paso de la racionalidad de valores propuesta por el idealismo alemán de Immanuel Kant ${ }^{44}$ a la racionalidad instrumental defendida por el empirismo escocés de David Hume ${ }^{45}$ Es decir, que Weber retoma la oposición entre la filosofía moral de dos autores, dos escuelas de pensamiento, dos tradiciones nacionales en suma (la Ilustración alemana y la escocesa), y la convierte en dicotomía que explica la diferente manera en que dos tipos de sociedades se organizan.

Como nos recordaba Alfonso Ortí, esto no debería perturbarnos demasiado: los modelos no son una transposición directa de la realidad, sino (cito sus palabras) "un Alef Borgiano, un punto de visión que nos permite contemplar el Universo" Los modelos tienen sentido en cuanto se plantean en una encrucijada histórica y contribuyen a resolverla. El riesgo del que debemos y podemos huir los historiadores es que dejemos de usar estos modelos como metáforas, y se conviertan para nosotros en corsés esterilizantes.

\footnotetext{
${ }^{41}$ Karl MarX, "Formen”, en Eric Hobsbawm. (ed.), Formaciones económicas precapitalistas, Mexico, S. XXI, 1979 (ed. original de 1858).

42 Jean Luc JAmARD, Anthropologies françaises en perspective. Presque-sciences et autres histoires, París, Kimé, 1993.

43 Alfonso OrTi y Cristóbal Gómez, "Costumbre contra ley en la vida del derecho", en Salustiano de Dios, Javier Infante y Eugenia Torijano (coords.), Historia de la propiedad: Costumbre y prescripción, Salamanca, 2006.

${ }^{44}$ Immanuel Kant, Lecciones de ética, Barcelona, Crítica, 2002 (ed. original de 1781).

${ }^{45}$ David Hume, A Treatise of Human Nature...

46 Alfonso OrTi y Cristóbal GómEz, "Costumbre contra ley...".
} 


\section{LOS ORÍGENES DE LA “GRAN División” ENTRE Historia y ANTROPOlOGÍA}

Antropología e Historia se diferenciaron como disciplinas académicas a finales del siglo XIX. En las grandes potencias europeas se fue consolidando, en lo que respecta al saber sobre el comportamiento del hombre en sociedad, una división en una serie de disciplinas: historia, sociología, antropología. Y además se produjo una división del trabajo en función del objeto. La historia empezó a reservarse al estudio del pasado de los pueblos con historia, con escritura, en particular los occidentales. Incluso toda una corriente pudo plantearse el ideal de una historia sin preconcepciones, conformándose al análisis de los datos, encarnados en documentos escritos ${ }^{47}$. Mientras, el análisis del ser humano en el presente europeo se configuraba como objeto de la sociología. Y finalmente la antropología se especializaba en los pueblos que estaban siendo absorbidos por Occidente: antropología física, estudio de la cultura material, análisis del parentesco, es decir, de formas sociales donde la primacía del individuo -del homo oeconomicus-aún no resultaba evidente.

En función en parte del objeto, pero también del hábito de trabajar separados, cada disciplina iba así generando una metodología propia. Pero en un principio, la división disciplinar no implicaba necesariamente incomunicación ${ }^{48}$. Cuando Karl Marx se enfrenta a la ingente tarea de redactar El Capital, pone en ella filosofía hegeliana, economía política ricardiana y mucha historia, pero también recurre con interés a la antropología (como es patente de manera clara en los Grundrisse). Por su parte Max Weber busca en la antigüedad griega y romana las claves que le permitan evaluar el éxito de una Europa decimonónica marcada por el capitalismo y el estado moderno: un dialogo entre sociología e historia que subyace a los diversos escritos que conforman Economía y Sociedad ${ }^{49}$, pero que es particularmente evidente en La ética protestante y el espíritu del capitalismo ${ }^{50}$, una de las obras sociológicas que más animaron la tarea de los historiadores en el siglo pasado. En cuanto a los antropólogos evolucionistas, no es que prescindieran completamente de la historia: privilegiaban las grandes leyes de la evolución humana (una historia "en sentido fuerte"), mientras otorgaban un interés menor a aquellos acontecimientos -que consideraban "contingentes"- que absorbían la atención de los historiadores ${ }^{51}$. Y así, a medida que historia, sociología y

\footnotetext{
47 Julián Casanova, La historia social y los historiadores, Barcelona, Crítica, 1991, págs. 10-14.

${ }^{48}$ Carmen Iglesias, Los origenes de la teoría sociológica: Montesquieu, Rousseau, Hegel, SaintSimon, Tocqueville, Comte, Marx, Spencer, Madrid, Akal, 1989.

${ }^{49}$ Max Weber, Economía y Sociedad. Esbozo de sociología comprensiva, México, Fondo de Cultura Económica, 1987 (ed. original de 1922).

${ }^{50}$ Max Weber, La ética protestante y el espiritu del capitalismo, Barcelona, Península, 1977 (ed. original de 1903).

${ }^{51}$ Jean Luc JAMARD, "Pueden equivocarse los antropólogos?...”.
} 
antropología se hacían progresivamente autónomas, se desarrollaba la idea de interdisciplinariedad, de importar conceptos y métodos de las otras disciplinas.

Las razones de la quiebra de esta interdisciplinariedad tienen mucho que ver con la influencia decisiva que iba a adquirir la obra del sociólogo francés Emile Durkheim (1858-1917) y la escuela que formó en torno a la revista L'Année Sociologique. Durkheim, inicialmente preocupado por estudiar los grandes procesos de la segunda mitad del siglo XIX (tales como la industrialización y urbanización, o la expansión colonial) se vio doblemente traumatizado por la derrota francesa en la Guerra Franco-Prusiana y por la Comuna revolucionaria de Paris: es decir por el impacto de dos grandes fenómenos, la nueva política de masas y la guerra de masas; y sus efectos que el identificó como propios de la desintegración social, o en su conocida expresión "anomia" 52 . ¿Por qué "los otros" -los primitivos, los campesinos, los europeos anteriores a la edad contemporánea- por qué todos ellos no parecían ver sus sociedades en peligro de implosión? La respuesta era clara: porque la división del trabajo y la diferenciación social era menor, y por ello representaciones colectivas y valores comunes generaban una conciencia colectiva que actuaba como cemento integrador ${ }^{53}$.

La hipótesis de Durkheim venía a racionalizar un lugar común en la cultura occidental: la existencia de una barrera con las sociedades no occidentales, apeadas de la senda triunfante de la historia y el progreso humano. Las sociedades occidentales contemporáneas, por el efecto combinado de la división del trabajo y la diferenciación social serían sociedades conformadas por individuos, donde la cohesión reposaba en la combinación de coerción e instituciones socializadoras (como la escuela). Por lo tanto la sociedad contemporánea necesitaba de disciplinas diferentes, que estudiaran respectivamente su presente y su pasado (historia y sociología) mientras que las sociedades primitivas (y más tarde los campesinos) fuera de la historia requerirían de una antropología.

Poco importa la validez de esta hipótesis. La escuela de L'Année Sociologique contaba con una gran capacidad organizativa y de publicaciones, empezando por la misma revista, y en la generación posterior a Durkheim las tres disciplinas aparecen ya netamente diferenciadas en el mundo académico francés, lideradas por primeros espadas que habían aceptado el principio de división del trabajo disciplinar, pero que compartían un patrimonio común derivado de la tradición durkheimiana. Maurice Halbwachs por la sociología ${ }^{54}$, Marcel Mauss por la an-

\footnotetext{
${ }^{52}$ De forma análoga a como otro de los grandes pioneros de los estudios sociales, el francés Ferdinand LE PLAY, se había quedado traumatizado por el impacto de las jornadas revolucionarias de 1848.

${ }^{53}$ Emile Durkheim, La division del trabajo social...

${ }^{54}$ Maurice Halbwachs, Los cuadros sociales de la memoria, Paris, Albin Michel, 1994 (ed. original de 1925).
} 
tropología ${ }^{55}$ y Lucien Febvre por la historia, son quizás las figuras más destacadas de esta primera generación de especialistas convencidos. A través de la figura de Lucien Febvre la historiografía francesa, con la naciente Escuela de los Annales, asumió esa división del trabajo entre disciplinas.

En la década de 1940 el modelo de división disciplinar y la teoría durkheimiana subyacente se implantó en el mundo académico anglosajón a ambas orillas del Atlántico, a través de dos reputados científicos sociales que mantenían estrechas relaciones: el antropólogo británico Radcliffe Brown ${ }^{56}$, y el sociólogo norteamericano Talcott Parsons ${ }^{57}$. Es lo que se ha dado en llamar funcionalismo o estructural-funcionalismo.

Radcliffe Brown había llegado a interesarse por las ideas de Durkheim a través de los estudios de este sobre los aborígenes australianos ${ }^{58}$ : unas ideas que le ayudaron a sistematizar sus posiciones en la histórica pugna que mantuvo con Bronislaw Malinowski. Las buenas relaciones que Radcliffe Brown fue capaz de establecer con sus homólogos norteamericanos a partir de los años 1930 le colocó muy pronto como un nodo clave en la concesión de becas de la Fundación Rockefeller, para financiar el trabajo de campo en Africa de las nuevas promociones de egresados en antropología. Algo que tuvo un papel no menor en la hegemonía de las ideas de Radcliffe Brown dentro de la antropología británica inmediatamente posterior a la Segunda Guerra Mundial.

Talcott Parsons por su parte realiza en los años 1930 una relectura de la obra de Durkheim y Weber, despojándolos de la preocupación por la contextualizacion histórica que caracterizaba sobre todo al segundo. Y elabora tres conceptos fundamentales: sistema social, diferenciación y valores.

Las bases para una visión sistémica de la sociedad las había puesto Pareto en 1916, al elaborar la noción de "sistema social", sobre el modelo que ofrecía el concepto de "sistema económico" en la economía política. La noción de Pareto ${ }^{59}$ contenía ya dos elementos contradictorios, cuyo peso no dejará de agravarse en desarrollos posteriores: el dinamismo que introduce la visión sistémica en la teorización de los procesos sociales se hace al precio de eliminar la contextualización histórica; y el "sistema social" se constituye en refugio de las actitudes y

\footnotetext{
${ }_{55}$ Marcel Mauss, "Essai su le don. Forme et raison de l'échange dans les sociétés archaiques", L'Anneé Sociologique, 1923-1924.

56 Archibald R. RAdCliffe Brown, Estructura y función en la sociedad primitiva, Barcelona, Península, 1974 (ed. original de 1952).

57 Talcott PARsons, La estructura de la acción social, Madrid, Guadarrama, 1968 (ed. original de 1937).

58 Emile Durkheim, Las formas elementales de la vida religiosa, Madrid, Akal, 1982 (ed. original de 1912).

59 Vilfredo PARETo, Traité de sociologie generale, París, Droz, 1968 (ed. original de 1916).
} 
pensamientos irracionales que no encuentran cabida en el "sistema económico". Parsons, en 1937, desarrolla ampliamente la idea, al distinguir cuatro "contextos" en la acción social, y teorizar consecuentemente la sociedad como conjunto de subsistemas -biológico, psíquico, social y cultural-, ordenados en una relación jerárquica ${ }^{60}$.

Consciente Parsons del imperativo en que se encontraba de explicar la relación entre los distintos subsistemas y reservar un espacio para el cambio social, elaboró un segundo concepto, la "diferenciación”, como el proceso rector del cambio social:

el hecho de que el estado en que se encuentra el orden social depende del equilibrio entre procesos de diferenciación y procesos de integración o control, y que la diferenciación rápida o excesiva produce desorden ${ }^{61}$.

Los cambios en el "sistema económico" activarían un doble proceso de diferenciación: en el subsistema social se produce una "segmentación” en colectivos o instituciones que desempeñan funciones especializadas; en el subsistema cultural, un proceso de "especificación" o diversificación de los valores y normas de los distintos colectivos. No se trata entonces de una simple dinámica del tipo "cambio económico provoca cambio social y este a su vez cambio cultural”. Lo que Parsons denomina "subsistema cultural", los valores y normas, son un modelo para la acción de los colectivos sociales, y su alteración constituye en cierta medida un prerrequisito para el cambio económico. Pero esta modificación de valores y normas priva a la sociedad de su cemento ideológico, la pone en peligro de desintegración social. Y obliga al estado a intervenir para evitar males mayores mediante las funciones de represión y socialización.

El modelo gozaba de un enorme atractivo para los teóricos sociales interesados en jugar un papel de consejeros en la planificación del cambio económico-social en las dos décadas posteriores a la Segunda Guerra Mundial:

Tales ideas [...]: primero, conectan los cambios en la comunicación, la estructura familiar, la actividad política, o cualquier otro fenómeno social con las alteraciones en la producción; segundo,

\footnotetext{
60 Talcott PARsons, La estructura de la acción social...

${ }^{61}$ Charles Tilly, Grandes estructuras, procesos amplios, comparaciones enormes, Madrid, Alianza, 1991, págs. 69-70.
} 
sugieren programas de acción-acelerando u orientando el proceso de modernización ${ }^{62}$.

La única potencia académica que hubiera podido plantear una alternativa a este modelo, aquella Alemania que se nutría del legado de Max Weber, había quedado descartada por el efecto acumulado de los años del nazismo y de la derrota en la Segunda Guerra Mundial. Por todas estas circunstancias, en las dos décadas posteriores a la guerra, lo que va a predominar en las historiografías europeas es una cierta incomunicación entre la historia, la sociología y la antropología ${ }^{63}$.

De esta incomunicación, en el mundo anglosajón, se lamentaba con acritud el historiador E.P. Thompson en 1971, en la introducción al ensayo "La economía moral de la multitud en la Inglaterra del siglo XVIII":

Son muchos, entre nosotros, los historiadores del desarrollo culpables de un craso reduccionismo económico que elimina las complejidades de motivación, conducta y función [...] Lo que es quizá un motivo de sorpresa es el clima intelectual-esquizoide, que permite a esta historiografia cuantitativa coexistir (en los mismos sitios y a veces en las mismas mentes) con una antropología social que deriva de Durkheim, Weber o Malinowski. Conocemos muy bien todo el delicado tejido de las normas sociales y las reciprocidades que regulan la vida de los isleños de Trobriand, y las energías psíquicas involucradas en el contenido de los cultos de Melanesia; pero, en algún momento, esta criatura social infinitamente compleja, el hombre melanesio, se convierte (en nuestras historias) en el minero inglés del siglo XVIII que golpea sus manos espasmódicamente sobre su estómago y responde a estímulos económicos elementales ${ }^{64}$.

Y paralelamente también los antropólogos se habían desentendido en todo el mundo de la historia y del estudio de las sociedades occidentales. De manera que cuando desde la década de 1970 la historiografía española se renueva a partir del contacto con la Ecole des Annales y con la historia marxista británica, hereda una historia que, aparentemente, no tiene mucho interés en dialogar con la antropología.

\footnotetext{
${ }^{62}$ Charles Tilly, Grandes estructuras... pág. 123.

${ }^{63}$ Santos Julia, Historia social/sociología histórica, Madrid, Siglo XXI, 1989, págs. 61-63.

${ }^{64}$ Edward P. Thompson, "La economía moral de la multitud en la Inglaterra del Siglo XVIII", Tradición, revuelta y conciencia de clase. Estudios sobre la crisis de la sociedad preindustrial, Barcelona, Crítica, 1979, págs. 64-65 (ed. original de 1971).
} 


\section{EsA ANTROPOlOGÍA QUE NOS LEGARON LOS GRANDES HISTORIADORES}

¿Quiere esto decir que los historiadores españoles de mi generación, que pasamos por las aulas de la universidad en la década de 1980, recibimos una educación carente de antropología? Todo lo contrario, estábamos recibiendo un montón de antropología y sociología, aunque no fuéramos conscientes plenamente de ello porque nos entraba de tapadillo a través de los historiadores que nosotros y nuestros profesores leíamos. Los grandes de la Escuela de los Annales y de la historiografía marxista británica oficialmente se habían desentendido de aquellas disciplinas afines. Pero en la práctica seguían leyendo a sociólogos y antropólogos y participaban con ellos en seminarios dentro de un mundo académico cuantitativamente mucho menos numeroso, donde los grandes se conocían y trataban personalmente, con independencia de su afiliación disciplinar. Y como historiadores tenían la misma necesidad que los antiguos griegos de contar con conceptos acerca de la naturaleza humana y la acción social, y con metodologías para enfrentarse a aquellas facetas del comportamiento humano que no dejaban plena huella en textos escritos. Y sin entender la antropología y sociología que nuestros maestros leían, nos resulta muy difícil contextualizar plenamente sus propios trabajos de los que aprendimos el oficio de historiador. Pondré apenas sendos ejemplos, correspondientes a la historia moderna y a la contemporánea: el primero es uno de los fundadores de la francesa Ecole des Annales, Lucien Febvre; el segundo es uno de los grandes de la historiografía británica de posguerra y en particular del "Grupo de Cambridge", Eric Hobsbawm.

En 1942 Lucien Febvre publica uno de los hitos fundamentales en la construcción de una "prehistoria" de las mentalidades, en concreto su magnífica obra El problema de la incredulidad en [la Francia de] el Siglo XVI ${ }^{65}$, que toma como objeto de estudio, como indica el subtítulo, "la religión de Rabelais". Nuestro autor decide abordar el universo de lo posible: es decir, dilucidar el carácter conservador, innovador o rupturista de la obra de Rabelais en el contexto de la Reforma. Estudia las obras de la ortodoxia católica, las de aquel Erasmo que rozaba según la Sorbona los límites de la heterodoxia, los trabajos rupturistas de Lutero y Calvino. De ahí pasa a abordar la ciencia de la época, la filosofía... la brujería, el conjunto de la cultura popular. Los franceses del siglo XVI, argumenta finalmente Febvre, no hubieran sido capaces de plantearse el ateismo como opinión con todas sus consecuencias. Basta con darse cuenta de que gentes del pueblo y filósofos compartían -nos dice- un universo mental poblado de hombres lobo, de sirenos y ondinas, de mártires como Saint Dennis que, después de que se les cortara la cabeza, echaban a correr con ella en las manos durante varios kilómetros.

\footnotetext{
${ }^{65}$ Lucien Febvre, El problema de la incredulidad en el siglo XVI: la religión de Rabelais, Madrid, Akal, 1963 (ed. original de 1942).
} 
¿Por qué? Porque esos antiguos franceses tenían una mentalidad prelógica que les impedía abordar sin prejuicios cuestiones como esas. Pues bien, Febvre no había extraído esta conclusión del estudio de los archivos y bibliotecas. Antes al contrario, constituía una premisa previa acerca de la naturaleza humana que había incorporado "prêt à porter" de la obra de uno de los grandes etnólogos franceses de principios del siglo XX, Lucien Levy-Bruhl: La mentalidad primitiva ${ }^{66}, E l$ alma primitiva ${ }^{67}$, y Lo sobrenatural y la naturaleza entre los primitivos ${ }^{68}$. Unos trabajos centrados en el análisis de los entonces llamados "pueblos primitivos" de Africa y Oceanía. En estas obras Levy-Bruhl afirmaba poder documentar exhaustivamente que en esos pueblos no existían límites claros entre la vigilia y el sueño, la vida y la muerte, lo material y lo espiritual, los humanos y los animales. "La individualidad es diferente para los primitivos de lo que lo es para nosotros [...] La dualidad y la bipresencia no se distinguen" (como reza el epígrafe con que resume el capítulo VI.V) ${ }^{69}$. Lo mismo, nos dice Febvre, que los franceses del S. XVI, que creían en hombres lobo:

Ayer nuestro maestro Lucien Lévy-Bruhl investigaba como y por qué razonaban los primitivos de modo distinto a los civilizados. En las diferentes épocas no se han seguido los mismos modos de razonamiento para formar los sistemas ideológicos ${ }^{70}$.

E insistía Febvre en el último capítulo de su "Rabelais" en lo siguiente:

los hombres del siglo XVI [...en] todo lo que en ellos pueda evocar esa 'mentalidad primitiva'71.

Esos hombres que según el historiador francés eran capaces de sentirse cómodos con las leyendas de seres humanos que se mudaban en animales:

se acomodaban [...] a situaciones [...] ambiguas o poco definidas, que pudieran parecernos absurdas o irritarnos: pensemos, por

\footnotetext{
${ }^{66}$ Lucien Levy-Bruhl, La mentalité primitive, París, PUF, 1960 (ed. original de 1922).

${ }^{67}$ Lucien Levy-Bruhl, El alma primitiva, Barcelona, Península, 1985 (ed. original de 1927).

${ }^{68}$ Lucien LeVy-Bruhl, Le surnaturel et la nature dans la mentalité primitive, París, PUF, 1963 (ed. original de 1931).

${ }^{69}$ Lucien LeVy-BruHL, El alma primitiva...

${ }^{70}$ Lucien FeBvre, El problema de la incredulidad..., pág. 11.

71 Íb. íbid., pág. 302.
} 
TODA HISTORIA LLEVA IMPLÍCITA UNA ANTROPOLOGÍA.

\title{
ejemplo, en las fronteras, llenas de enclaves, de una Francia sin límites estrictos ${ }^{72}$
}

La justicia de aquel tiempo no conocía límites entre el hombre y el animal. El cerdo que mata a un hombre o se come a un niño es juzgado como un criminal y ahorcado por sentencia judicial ${ }^{73}$.

Y no solo no poseían la noción de posible en relación a imposible; aquellos hombres del siglo XVI no poseyeron tampoco nuestra noción de natural en oposición a sobrenatural ${ }^{74}$.

Y en relación a esos santos que envíaban las plagas para después ponerles fin una vez que sus víctimas invocaran su intercesión mediante plegarias, Febvre les aplica la siguiente frase:

\begin{abstract}
'el que sabe curar una enfermedad tiene ese poder porque es también capaz de producirla' [... esa] es una constatación de Lévy-Bruhl interpretando los sentimientos de los primitivos ${ }^{75}$.
\end{abstract}

Pero cuando Febvre lleva estas ideas hasta sus últimas consecuencias es en el Capítulo 2 de la segunda parte del libro, cuando aborda la cuestión del "Utillaje mental: palabras que faltaban" [al francés del siglo XVI]:

las palabras con que contaban aquellos hombres cuando razonaban en francés sobre las ciencias, o cuando razonaban tan sólo, no estaban hechas para el razonamiento, la explicación o la demostración. No eran palabras sabias, sino palabras de la lengua vulgar"76.

Para culminar en el epígrafe siguiente, en que esgrimía como argumento definitivo las inadecuaciones de la sintaxis del francés de la época:

El francés antiguo [...] del siglo XII, cuyo verbo ocupaba el segundo lugar [...] su anárquica libertad y el perfecto desorden de sus construcciones, y la continua confusión de tiempos, simples y perfectos,

\footnotetext{
72 Lucien FeBvre, El problema de la incredulidad..., pág. 303. El subrayado con negrita es nuestro.

73 Íb. ibid., pág. 304.

74 Íb. ibid., págs. 305.

75 Íb. íbid., pág. 306. La frase es de LEVY-BRUHL, L., Le surnaturel et la nature...

${ }^{76}$ Lucien Febvre, El problema de la incredulidad..., pág. 249.
} 
tan fastidiosa hoy para nosotros [...] no existe perspectiva, con la consiguiente dificultad para interpretar los confusos designios de los autores antiguos ${ }^{77}$.

La concordancia de los tiempos es irregular [...] Tampoco el orden de las palabras está rigurosamente fijado. A menudo el verbo adelanta al sujeto ${ }^{78}$.

Es porque la sintaxis no depende de un hombre, aunque sea un genio; es una institución social [...] Y cada época y cada grupo tendrán la sintaxis que se merecen: quiero decir una sintaxis en relación con su grado de desarrollo intelectual y de conocimiento científico ${ }^{79}$.

Dado que Febvre no podía observar directamente a sus franceses del siglo XVI, les reconocía ciertas características mentales similares a los "primitivos" de las colonias, respecto a los que tanto el como Levy-Bruhl no podían evitar exhibir cierta sensación de superioridad. ¿Y acaso no era esa una operación similar a la que por la misma época realizaban en los estudios de prehistoria el abate Breuil ${ }^{80}$ o Teilhard de Chardin ${ }^{81}$ cuando interpretaban el arte rupestre magdaleniense como producto también de una mentalidad prelógica, como prácticas de magia propiciatoria que pretendía facilitar la caza de los grandes mamíferos representados en las paredes de las cuevas?

La barrera de incomunicación entre historia y antropología en el mundo académico francés era real, y aún se haría más fuerte con la influencia de Claude Levy Strauss, un antropólogo de extraordinario talento, pero que sentía un interés más que limitado por la historia. Con él, la atribución a historia y antropología de dominios de estudio diferentes dejaría incluso de fundamentarse en una cuestión de fuentes -sociedades con y sin escritura- para basarse en la misma naturaleza de los grupos humanos implicados: la distinción entre sociedades frías y sociedades calientes ${ }^{82}$.

Pero la supuesta muralla que habría aislado a las generaciones de antropólogos e historiadores anterior y posterior a la Segunda Guerra Mundial también tenía muchas fisuras. En último término esa incomunicación casi absoluta pertenece

\footnotetext{
${ }^{77}$ Lucien Febvre, El problema de la incredulidad..., pág. 250.

${ }^{78}$ Íb. íbid., pág. 251.

79 Íb. íbid., pág. 252. El subrayado con negrita es nuestro.

${ }^{80}$ Henri Breuil, Quatre cents siècles d'art parietal, Centre d'Etudes et de Documentation Préhistoriques, 1952.

${ }^{81}$ Pierre Teilhard de Chardin, La place de l'homme dans la nature. Le groupe zoologique humaine, Paris, Union Générale d'Editions, 1956 (ed. original de 1949).

${ }^{82}$ Claude Levy Strauss, "Histoire et ethnologie", Annales ESC, 1983, págs. 1217-1231.
} 
también en parte a la mitología elaborada ad hoc para legitimar la fragmentación de las ciencias sociales en disciplinas independientes. Como documentan los recuerdos del antropólogo británico Jack Goody ${ }^{83}$, el contacto con el mundo de los Annales, mucho más abierto al diálogo interdisciplinar, permitió a historiadores y antropólogos anglosajones realizar un curioso intercambio de ideas "a través de terceros". Baste pensar en la figura de Marc Bloch, en la incidencia que tuvo la segunda edición de The Golden Bough (1915) del antropólogo inglés James Frazer ${ }^{84}$ sobre Les rois thaumaturgues (1924) de Bloch ${ }^{85}$. O en la influencia que recíprocamente ejerció La société féodale (1940) de Bloch ${ }^{86}$ sobre los antropólogos africanistas británicos de la posguerra como Max Gluckman.

En el propio mundo académico británico hay una temprana tradición de intercambios entre antropólogos e historiadores. El segundo ejemplo que voy a tratar aquí procede del encuentro entre la generación de antropólogos estructural funcionalistas que siguieron a Radcliffe Brown y los historiadores marxistas del Grupo de Cambridge.

Uno de los episodios más brillantes de este intercambio de ideas fue aquel seminario que en 1956 reunió a algunos de ellos en Manchester en torno a la figura de Max Gluckman, para discutir sobre las movilizaciones populares pre-industriales. Ese encuentro alimentó obras "antropológicas" tan importantes como Order and Rebellion in Tribal Africa (1963) del propio Gluckman ${ }^{87}$, o As the Trumpet Sounds (1957), el estudio de Peter Worsley sobre los cultos "cargo" de Melanesia ${ }^{88}$. Pero también infundió nueva savia a obras de historia tan centrales como el Primitive Rebels (1959) de Eric Hobsbawm ${ }^{89}$, o En pos del milenio. Revolucionarios milenaristas y anarquistas místicos de la Edad Media (1957) de Norman Cohn ${ }^{90}$.

Dejemos hablar a Hobsbawm en el prefacio a la primera edición de sus $R e$ beldes primitivos:

\footnotetext{
${ }^{83}$ Jack Goody, "De la historia a la antropología. Miradas sobre las antropologías británica y francesa", El hombre, la escritura y la muerte. Conversación con Pierre-Emmanuel Dauzat, Barcelona, Península, 1988, págs. 54-75.

${ }^{84}$ James Frazer, La rama dorada. Magia y religión, México, Fondo de Cultura Económica, 1956 (ed. original de $1915-2^{\mathrm{a}}$ edición).

${ }^{85}$ Marc Bloch, Los Reyes taumaturgos, México, Fondo de Cultura Económica, 1988 (ed. original de 1924).

${ }^{86}$ Marc BLoch, La sociedad feudal, Madrid, Akal, 1987 (ed. original de 1940).

${ }^{87}$ Max Gluckman, Order and Rebellion in Tribal Africa, Londres, Cohen \& West, 1963.

${ }^{88}$ Peter Worstey, Al son de la trompeta final. Un estudio de los cultos "cargo" en Melanesia, Madrid, Siglo XXI, 1980 (ed. original de 1957).

${ }^{89}$ Eric Hobsbawm, Rebeldes primitivos. Estudio sobre las formas arcaicas de los movimientos sociales en los sglos XIX y XX, Barcelona, Ariel, 1967 (ed. original de 1959).

${ }^{90}$ Norman CoHN, En pos del milenio. Revolucionarios milenaristas y anarquistas místicos de la Edad Media, Madrid, Alianza, 1989 (ed. original de 1957).
} 
El profesor Max Gluckman gestionó para mí una invitación en 1956 con el fin de que pronunciase tres conferencias [...] en la Universidad de Manchester, donde tuve la feliz oportunidad de discutir el asunto con el y con un grupo de antropólogos, historiadores, economistas y estudiosos de la ciencia política, entre los que figuraban expertos en los movimientos milenarios de la talla del doctor Peter Worsley y del profesor Norman Cohn. Este libro es una ampliación de tales conferencias ${ }^{91}$.

Max Gluckman había llegado a Manchester en 1949 para hacerse cargo de la cátedra de antropología social. Allí desarrolló una visión muy sensible al conflicto y alejada del funcionalismo estructuralista de Radcliffe Brown o de Evans Pritchard. En Order and Rebellion in Tribal Africa (1963) Gluckman analiza las rebeliones en los reinos Swazi o Zulú del Africa central como mecanismos homeostáticos, que no pondrían en cuestión el orden social y político sino que en última instancia lo reforzarían: se trataría de luchas entre facciones por controlar la sucesión de un reino, o de movimientos "desde abajo" para exigir que se restaurase el orden tradicional de las cosas.

Creo que me dejé llevar por el deseo de atraer la atención de algún historiador, que pudiera estar escuchando, hacia nuestros análisis antropológicos ${ }^{92}$.

Resulta de particular interés el texto que dedicó Gluckman a la rebelión "Mau Mau" de los kikuyu, que va a sacudir la Kenia colonial en la década de 1950. El texto aparece recopilado en Order and rebellion in Tribal Africa (1963), pero según Ortuño procede de un texto anterior radiado por la BBC en 1954, dos años después del comienzo de la revuelta:

Según la explicación de Gluckman, la revuelta Mau Mau hay que enmarcarla dentro de un proceso general de desestructuración social como consecuencia de la ocupación y el dominio colonial [...] ante la necesidad que tienen los africanos de controlar los procesos sociales y económicos [...], acaban por buscar en lo sobrenatural la

\footnotetext{
${ }^{91}$ Eric HobsBawm, Rebeldes primitivos..., pág. 5.

${ }^{92}$ Max Gluckman, Order and Rebellion... Citado en José María Ortuño, "Orden y rebelión en las sociedades africanas: propuesta de un replanteamiento teórico", Actas del VIII Congreso de Antropología de la FAAEE, Vol. 4: Antropología jurídica, Santiago de Compostela, FAAEE, 1999, pág. 43.
} 
explicación de lo que sienten pero no entienden. [El Mau Mau sería] un movimiento nihilístico de desesperación - matar y ser matadocon un uso extenso de la magia y de juramentos para contrarrestar una fuerza que se les presenta sobrecogedora ${ }^{93}$.

En 1954 se incorporaba a Manchester el antropólogo Peter Worsley, que estaba preparando su libro sobre los cultos cargo en Melanesia, que publicaría tres años más tarde. Worsley documenta como en las religiones pre-coloniales de la Melanesia los fieles se congregaban para invocar el advenimiento de los antepasados en grandes canoas cargadas de regalos, canoas similares a las que en la práctica los indígenas utilizaban para el intercambio "comercial" y la guerra. Pero la experiencia de ocupación colonial por franceses, holandeses, alemanes y británicos, y la implantación de una economía de plantación generó un incremento extraordinario de la circulación de riqueza y de frustración por su reparto desigual. Mientras que las misiones protestantes, en particular aquellas más marcadamente evangélicas, dieron complejidad a las ideas religiosas. Y conforme los ejércitos coloniales se enfrentaban en aquellos mares en la Primera y en la Segunda Guerra Mundial, los indígenas empezaron a desarrollar cultos milenaristas originales, uno de cuyos elementos centrales vendría a ser la construcción de aeropuertos de bambú (incluídos los aparatos de radio) para invocar el "cargo", el advenimiento de los antepasados cargados de regalos -ahora latas de conserva, armas, muy pronto electrodomésticos- que vendrían a poner fin a la dominación colonial.

En 1959 Eric Hobsbawm publicaba Primitive Rebels, uno de los hitos fundadores de la "historia desde abajo". En este libro Hobsbawm pasaba revista a ejemplos tan diversos como bandoleros sicilianos del siglo XIX, anarquistas andaluces, movimientos campesinos del Perú, o "la Violencia" en la Colombia posterior a la $2^{\text {a }}$ Guerra Mundial. El subtítulo del libro dejaba las cosas bastante claras: "Estudio sobre las formas arcaicas de los movimientos sociales en los siglos XIX y XX". Y aún más el calificativo de "milenarismo" que otorgaba a algunos de ellos, incluidas las "sectas obreras", la conversión al metodismo de amplios sectores del primer sindicalismo inglés. Resulta llamativo que, Hobsbawm, a lo largo de Rebeldes Primitivos, acabara marcando distancias respecto a En pos del milenio del historiador Norman Cohn, en los que este abordaba movilizaciones populares como las que acompañaron a la Primera Cruzada, la rebelión campesina alemana de principios del siglo XVI, o los anabaptistas de la ciudad de Münster. En cambio el historiador británico abrazaba con interés los estudios sobre el mismo fenómeno en la Melanesia colonial a cargo del antropólogo Peter Worsley.

\footnotetext{
${ }_{93}$ Max Gluckman, Order and Rebellion in Tribal Africa... Citado en José María Ortuño, “Orden y rebelión...", p. 47.
} 
Los cultos milenaristas en Oceanía a principios del siglo XX, las revueltas en los reinos tribales del Africa subsahariana del siglo XIX, las rebeliones campesinas en la Europa tardomedieval, el bandidaje y el ludismo en la Europa y América que veían el amanecer de la revolución industrial, todos ellos se interpretaron a partir de la teoría de Durkheim -y de Parsons- como ejemplos de la reacción exasperada de multitudes preindustriales ante las amenazas de la modernidad. El común denominador a todas estas situaciones lo constituiría el efecto disgregador generado por las fuerzas emergentes del capitalismo y del estado moderno que convulsionaban a las sociedades tradicionales: fuerzas que actuarían ya en la Inglaterra y Francia bajomedieval, afectarían a las periferias celta y mediterránea de Europa a principios del siglo XIX, medio siglo más tarde estarían ejerciendo su impacto en el Africa anterior a la Conferencia de Berlín, y sus últimas olas llegarían a Oceanía poco antes de la Gran Guerra.

Todo lo cual lo podríamos resumir del modo siguiente: a partir de 1946, coincidiendo con la publicación de los Estudios sobre el desarrollo del capitalismo de Maurice Dobb ${ }^{94}$, se va constituyendo el "grupo de Cambridge" de historiadores marxistas británicos. Muy pronto algunos de ellos se plantean el problema de la alternativa rebelión vs. revolución en la Europa medieval y moderna, y el papel que en ella habrían jugado las ideas religiosas ${ }^{95}$. Dentro de este grupo, Eric Hobsbawm apuesta temporalmente por aproximarse a la antropología de Manchester, quizás la variante del estructural-funcionalismo que, sin romper abiertamente con Radcliffe Brown, mostraba mayor sensibilidad hacia la historia. La conexión estaba servida con Georges Rudé, un historiador que acaba de contactar en Francia con los trabajos de Georges Lefebvre ${ }^{96}$, y con la polémica que este había mantenido con Gustave Le Bon ${ }^{97}$, el padre de la psicología colectiva, a propósito del papel de las multitudes en la Revolución francesa: criminales irracionales para Le Bon, justicieros racionales para Lefebvre. A su vez Rudé intentaba retomar la polémica a partir del uso de dicotomías parsonianas: multitudes "preindustriales o industriales", "tradicionales o modernas"98. Y ya está servida la conexión, que se plasmará en la colaboración en Capitán Swing ${ }^{99}$, entre Rudé y un Hobsbawm

\footnotetext{
${ }^{94}$ Maurice DoBB, Estudios sobre el desarrollo del capitalismo, Madrid, Siglo XXI, 1971 (ed. original de 1946).

${ }^{95}$ Christopher Hitl Puritanism and Revolution: Studies in interpretation of the English Revolution of the 17th Century, Londres, Secker and Warbury, 1958.

${ }^{96}$ Georges Lefebvre, La Grande Peur de 1789, Felix Alcan ed., 1932.

${ }^{97}$ Gustave Le Bon, La Révolution Française et la psychologie des révolutions, París, Flammarion, 1912.

${ }^{98}$ Georges Rude, The Crowd in History. A Study of Popular Disturbances in France and England, 1730-1848, Nueva York, Wiley \& Sons, 1964.

${ }^{99}$ Georges Rude \& Eric Hobsbawm, Revolución industrial y revuelta agraria: el Capitán Swing, Madrid, Siglo XXI, 2009 (ed. original de 1969).
} 
que se dejaba seducir por una antropología -la de Manchester- no muy distante de la sociología parsoniana. Como el mismo Hobsbawm escribiría más adelante:

[En Gran Bretaña] la antropología social ha sido la disciplina crucial en las ciencias sociales, al menos la única que algunos historiadores, yo incluido, han encontrado interesante y de la que han podido sacar algún beneficio ${ }^{100}$.

Lucien Febvre y Eric Hobsbawm fueron dos historiadores extraordinarios. La cuestión no es que se "equivocaran": simplemente entre sus premisas incorporaban una antropología que hoy en día sería necesario revisar. ¿Y como accedieron a esa antropología? La clave, y esta es mi hipótesis, es que las redes de relaciones personales que supieron tejer antropólogos e historiadores entre sí, les permitieron superar el aislamiento relativo que les imponía el proceso de construcción de sus respectivas disciplinas, y beneficiarse de las teorías y métodos del conjunto de las ciencias sociales. Es algo implícito en el conjunto de la obra de E.P. Thompson, que sería incomprensible sin tener en cuenta esta fertilización antropológica. Algo evidente en aquella invocación a Durkheim, Weber y Malinowski en las páginas de "La economía moral de la multitud...", o en el hecho de que "Tiempo, disciplina de trabajo y capitalismo industrial" "101 (1967) se abra con citas extensas a los trabajos de Evans Pritchard, sobre los ganaderos Nuer del Sudán Anglo egipcio ${ }^{102}$ y a la obra de Pierre Bourdieu sobre el campesinado de las kabylas argelinas ${ }^{103}$.

Es en último término lo que se desprende de los recuerdos de Jack Goody, que evoca cómo conoció en Cambridge en 1939 a E.P. Thompson y a Eric Hobsbawm, y cómo a partir de "nuestros comunes intereses antropológicos y literarios" se fue construyendo una relación de amistad e intercambio intelectual, que les llevó a coincidir en múltiples foros, alguno tan señero como el consejo de redacción de la revista Past and Present ${ }^{104}$, fundada en 1952.

La incomunicación relativa entre antropología e historia que caracterizó al mundo académico en las décadas de 1940-50 no se mantuvo mucho tiempo. Al igual que algunos historiadores echaban de menos el contacto con las demás ciencias sociales, en la década de 1960 algunos antropólogos habían vuelto sus

\footnotetext{
${ }^{100}$ Citado en Julián CAsanova, La historia social..., pág. 93.

${ }^{101}$ Edward P. ThOMPson, "Tiempo, disciplina de trabajo y capitalismo industrial", Tradición, revuelta y conciencia de clase. Estudios sobre la crisis de la sociedad preindustrial, Barcelona, Crítica, 1979, págs. 239-293 (ed. original de 1967).

${ }^{102}$ Edward Evans-Pritchard, Los Nuer, Barcelona, 1977 (ed. original de 1940).

${ }^{103}$ Pierre Bourdieu, "The Attitude of the Algerian Peasant toward Time", en J. Pitt-Rivers (ed.), Mediterranean Countrymen, Paris, 1963, págs. 55-72.

104 Jack Goody, "De la historia a la antropología...".
} 
ojos a Occidente, en particular a los estudios sobre el campesinado, de la mano de autores como Pierre Bourdieu (en Francia) y Eric Wolf ${ }^{105}$ (en el mundo anglosajón). Y habían aplicado a los estudios campesinos las metodologías que habían desarrollado para estudiar a las sociedades no occidentales. Para paliar la escasez de documentos por escrito adoptaron el trabajo de campo, basado en la observación directa del comportamiento social y el estudio de la memoria oral, las genealogías o el análisis de la cultura material. Y ante la ausencia relativa de instituciones formales y centralizadas como la empresa o el estado desplazaron su interés al estudio del parentesco, las redes sociales, las relaciones clientelares o la cultura oral.

Este movimiento se vio correspondido por otro inverso, realizado por unos historiadores que, aquí y allá, se interesaban por el aparato teórico y la metodología antropológica: los ya citados ejemplos ingleses; en Francia los historiadores cobijados en la sección VI de la Ecole Pratique des Hautes Etudes... y tantos otros.

Pero esa es, ya, otra historia

\section{CONCLUSIONES}

Mucho se ha escrito sobre las virtudes y peligros del diálogo interdisciplinar, entendido como intercambio entre disciplinas perfectamente definidas. Lo que he pretendido argumentar en este artículo es algo un poco diferente: que todo historiador lleva a un sociólogo o a un antropólogo en la cabeza... bueno, normalmente a varios. Porque, en definitiva, cualquier historiador precisa contar con teorías acerca de la naturaleza humana, de la organización social o de la acción colectiva. En el pasado, de todo esto se encargaba en Occidente una disciplina llamada filosofía, y la familiaridad con ella formaba parte del bagaje básico de cualquier "hombre -o mujer- de letras".

El proceso a través del cual historia, sociología, psicología o antropología marcaron distancias con la filosofía y se definieron como disciplinas independientes, comienza en la segunda mitad del siglo XIX y se consolida en el periodo de entreguerras, hasta alcanzar su máxima expresión tras la $2^{\mathrm{a}}$ Guerra Mundial. Hasta hoy. Nada que objetar en principio a esta especialización interdisciplinar. Después de todo ya lo decía Durkheim, la sociedad contemporánea se caracteriza por el principio de división del trabajo. Pero especialización no conlleva necesariamente incomunicación. La antropología y la sociología han proseguido el debate con los clásicos $^{106}$ : siguen interesados por las discusiones acerca de la naturaleza humana

\footnotetext{
${ }^{105}$ Eric Wolf, Los campesinos, Barcelona, Labor, 1982.

${ }^{106}$ Marvin HARRIS, El desarrollo de la teoría antropológica. Una historia de las teorías de la cultura, Madrid, Siglo XXI, 1979.
} 
(los primeros) o la acción colectiva (los segundos). Por eso el antropólogo Marshall Sahlins, en Economía de la Edad de Piedra, dedicaba uno de sus capítulos más importantes a discutir los "Aspectos políticos de El [Ensayo sobre el] Don [de Mauss] y El Leviatan [de Hobbes]"107. Por eso el también antropólogo Louis Dumont ${ }^{108}$ dedica una de sus obras centrales a analizar los orígenes del pensamiento económico, entendido este como la teoría "emic" -la interpretación no científica, indígena- que utilizan los "pueblos" occidentales. Y ello en contraste con la teoría "etic", científica, que emplearían los antropólogos para estudiar a los académicos, entre ellos a la "tribu" de los economistas ${ }^{109}$.

Cuando los historiadores recurren de manera deliberada a disciplinas afines, en busca de conceptos sobre la naturaleza humana o la acción social, el resultado puede ser muy enriquecedor. Buena prueba de ello han sido los debates en sociología histórica, en particular los trabajos de Charles Tilly a partir de la obra de Barrington Moore ${ }^{110}$ o Theda Skocpol ${ }^{111}$. Aún de mayor actualidad son los estudios sobre la memoria y los lugares de la memoria, que juegan un papel central en la historiografía francesa y española reciente sobre la edad contemporánea. Unos estudios cuyo padre fundador fue Pierre Nora ${ }^{12}$, a partir de la recuperación de conceptos centrales en la obra del sociólogo francés Maurice Halbwachs ${ }^{113}$.

El riesgo no reside, creo yo, en una "sobredosis" de interdisciplinariedad, sobre todo cuando el historiador tiene la cabeza bien amueblada por una formación académica seria -y no debería haber dudas de que la española lo es-. El riesgo estribaría más bien en el caso improbable de que el historiador pudiera soñar con practicar una disciplina que no precisara de las ciencias sociales. Podría acabar, en ese caso, utilizando inadvertidamente las ideas acerca del ser humano o de la acción colectiva inscritas por la tradición occidental en nuestro "repertorio", y en el de los historiadores que leemos. Podría acabar por aplicar en sus obras "históricas" las ideas del "homo oeconomicus" de Bernard Mandeville, la antropología política de Thomas Hobbes o, por qué no, la de San Agustín.

\footnotetext{
${ }^{107}$ Marshall SAhlins, Economía de la Edad de Piedra, Madrid, Akal, 1977, págs. 190-202.

${ }^{108}$ Louis Dumont, Homo Aeaqualis...

${ }^{109}$ Para un conocido ejercicio de análisis "antropológico" de la comunidad científica, ver Bruno Latour, Nous n'avons jamais été modernes. Essai d'anthropologie symétrique, París, Ed. La Découverte, 1991.

${ }^{110}$ Barrington Moore, Los orígenes sociales de la dictadura y la democracia. El señor y el campesino en la formación del mundo moderno, Barcelona, Península, 1973.

111 Theda Skocpol, States and Social Revolutions: A Comparative Analysis of France, Russia, and China, Nueva York, Cambridge University Press, 1979.

112 Pierre Nora, Les lieux de mémoire. I: La République. II: La Nation. III: Les Français, París, Gallimard, 1984-1993.

${ }^{113}$ Maurice Halbwachs, Los cuadros sociales de la memoria...
} 


\section{BIBLIOGRAFÍA}

Agustín de Hipona, La Ciudad de Dios, México, Porrúa, 1970.

Aristóteles, La Politica, Madrid, Espasa Calpe, 1995.

Bloch, Marc, La sociedad feudal, Madrid, Akal, 1987.

Bloch, Marc, Los Reyes taumaturgos, México, Fondo de Cultura Económica, 1988.

Bourdieu, Pierre, "The Attitude of the Algerian Peasant toward Time", en J. Pitt-Rivers (ed.), Mediterranean Countrymen, Paris, 1963, págs. 55-72.

Breuil, Henri, Quatre cents siècles d'art parietal, Centre d'Etudes et de Documentation Préhistoriques, 1952.

Cardesín, José María, "Miseria de la Teoría... de la Modernización: una revisión de algunos estudios sociológicos sobre el mundo rural contemporáneo", Agricultura y Sociedad, 84 (1997), págs. 141-164.

Cardesín, José María y Ruiz, Beatriz (coords.), Antropología Hoy. Teorías, técnicas, tácticas, Monográfico de Areas. Revista de Ciencias Sociales, 19 (1999), 286 págs.

Casanova, Julián, La historia social y los historiadores, Barcelona, Crítica, 1991.

Cohn, Norman, En pos del milenio. Revolucionarios milenaristas y anarquistas místicos de la Edad Media, Madrid, Alianza, 1989.

Darwin, Charles, The Descent of Man and Selection in Relation to Sex, Londres, Murray, 1871.

Detienne, Marcel, "Si, por casualidad, un antropólogo se encuentra con un historiador" Comparar lo incomparable. Alegato a favor de una ciencia histórica comparada, Barcelona, Península, 2001, págs. 17-41.

Dobb, Maurice, Estudios sobre el desarrollo del capitalismo, Madrid, Siglo XXI, 1971.

Dumont, Louis, Ensayos sobre el individualismo. Una perspectiva antropológica sobre la ideología moderna, Madrid, Alianza, 1987.

Dumont, Louis, Homo aequalis. Génesis y apogeo de la ideología económica, Madrid, Taurus, 1982.

Durkheim, Emile, La división del trabajo social, Barcelona, Planeta, 1985.

Durkheim, Emile, Las formas elementales de la vida religiosa, Madrid, Akal, 1982.

Evans Pritchard, Edward, Los Nuer, Barcelona, 1977.

Febvre, Lucien, El problema de la incredulidad en el siglo XVI: la religión de Rabelais, Madrid, Akal, 1963.

Frazer, James, La rama dorada. Magia y religión, México, Fondo de Cultura Económica, 1956.

Ginzburg, Carlo, Por reverència terror. Llegir Hobbes avui, Barcelona, Arcadia, 2009.

Gluckman, Max, Order and Rebellion in Tribal Africa, Londres, Cohen \& West, 1963.

Goody, Jack, "De la historia a la antropología. Miradas sobre las antropologías británica y francesa", El hombre, la escritura y la muerte. Conversación con Pierre-Emmanuel Dauzat, Barcelona, Península, 1988, págs. 54-75.

Gregorio de Tours, Histoire des Francs, París, Ed. Belles Letres, 1980.

Halbwachs, Maurice, Los cuadros sociales de la memoria, Paris, Albin Michel, 1994. 
TODA HISTORIA LLEVA IMPLÍCITA UNA ANTROPOLOGÍA.

Harris, Marvin, El desarrollo de la teoría antropológica. Una historia de las teorías de la cultura, Madrid, Siglo XXI, 1979.

Hegel, G.W. Friedrich, Lecciones sobre la filosofia de la historia universal, Madrid, Alianza, 1994.

Hill, Christopher, Puritanism and Revolution: Studies in interpretation of the English Revolution of the 17th Century, Londres, Secker and Warbury, 1958.

Hobbes, Thomas, Leviatán, o La materia, forma y poder de una república, eclesiástica y civil, México, Fondo de Cultura Económica, 1992.

Hobsbawm, Eric, Rebeldes primitivos. Estudio sobre las formas arcaicas de los movimientos sociales en los siglos XIX y XX, Barcelona, Ariel, 1967.

Hume, David, A Treatise of Human Nature, Oxford, Clarendon Press, 1978.

Iglesias, Carmen, Los orígenes de la teoría sociológica: Montesquieu, Rousseau, Hegel, Saint-Simon, Tocqueville, Comte, Marx, Spencer, Madrid, Akal, 1989.

Jamard, Jean Luc, Anthropologies françaises en perspective. Presque-sciences et autres histoires, París, Kimé, 1993.

Jamard, Jean Luc, "Pueden equivocarse los antropólogos? Antropología, ciencias e historia", en José María Cardesín y Beatriz Ruiz, (coords.), Antropología Hoy. Teorías, técnicas, tácticas, Monográfico de Areas. Revista de Ciencias Sociales, 19 (1999), págs. 256-286.

Jenofonte, Anábasis, Madrid, Gredos, 1991.

Juliá, Santos, Historia social/sociología histórica, Madrid, Siglo XXI, 1989.

Kant, Immanuel, Lecciones de ética, Barcelona, Crítica, 2002.

Latour, Bruno, Nous n'avons jamais été modernes. Essai d'anthropologie symétrique, París, Ed. La Découverte, 1991.

Le Bon, Gustave, La Révolution Française et la psychologie des révolutions, París, Flammarion, 1912.

Lefebvre, Georges, La Grande Peur de 1789, Felix Alcan ed., 1932.

Levy Strauss, Claude, "Histoire et ethnologie", Annales ESC, 1983, págs. 1217-1231.

Lévy-Bruhl, Lucien, La mentalité primitive, París, PUF, 1960.

Lévy-Bruhl, Lucien, El alma primitiva, Barcelona, Península, 1985.

Lévy-Bruhl, Lucien, Le surnaturel et la nature dans la mentalité primitive, París, PUF, 1963.

Locke, John, Primer y Segundo Ensayo sobre el Gobierno Civil, Madrid, Espasa-Calpe 1991.

Maine, Henry S., Ancient Law, Londres, The World's Classics, 1961.

Malthus, Thomas, Ensayo sobre el principio de la población, México, Fondo de Cultura Económica, 1951.

Mandeville, Bernard, La fábula de las abejas. Los vicios privados hacen la prosperidad pública, Madrid, Fondo de Cultura Económica, 2004.

Maquiavelo, Nicolás, El príncipe, Madrid, Alianza, 2010.

Martín de Dumio, De Correctione Rusticorum, A Coruña, Espiral Maior, 1997.

Marx, Karl, "Formen", en Eric Hobsbawm. (ed.), Formaciones económicas precapitalistas, Mexico, S. XXI, 1979. 
Mauss, Marcel, "Essai su le don. Forme et raison de l'échange dans les sociétés archaiques", L'Anneé Sociologique, 1923-1924.

Mills, Colin W., La imaginación sociológica, México, Fondo de Cultura Económica, 1961.

Moore, Barrington, Los orígenes sociales de la dictadura y la democracia. El señor y el campesino en la formación del mundo moderno, Barcelona, Península, 1973.

Nora, Pierre, Les lieux de mémoire. I: La République. II: La Nation. III: Les Français, París, Gallimard, 1984-1993.

Ortí, Alfonso y Gómez, Cristóbal, “Costumbre contra ley en la vida del derecho", en Salustiano de Dios, Javier Infante y Eugenia Torijano (coords.), Historia de la propiedad: Costumbre y prescripción, Salamanca, 2006.

Ortuño, José María, "Orden y rebelión en las sociedades africanas: propuesta de un replanteamiento teórico", Actas del VIII Congreso de Antropología de la FAAEE, Vol. 4: Antropología jurídica, Santiago de Compostela, FAAEE, 1999, págs. 41-54.

Pablo de Tarso, Carta a los Romanos, Sagrada Biblia, Madrid, BAC, 1873.

Pareto, Vilfredo, Traité de sociologie generale, París, Droz, 1968.

Parsons, Talcott, La estructura de la acción social, Madrid, Guadarrama, 1968.

Platon, Fedro, en Obras completas, Madrid, Aguilar, 1993.

Platon, La República, en Obras completas, Madrid, Aguilar, 1993.

Polibio de Megalópolis, Historia de Roma, Madrid, Alianza, 2008.

Radcliffe Brown, Archibald R., Estructura y función en la sociedad primitiva, Barcelona, Península, 1974.

Ricardo, David, Principios de economía política y tributación, Madrid, Pirámide, 2003.

Rousseau, Jean Jacques, El contrato social, Madrid, Espasa-Calpe, 1980.

Rudé, Georges \& Hobsbawm, Eric, Revolución industrial y revuelta agraria: el Capitán Swing, Madrid, Siglo XXI, 2009.

Rudé, Georges, The Crowd in History. A Study of Popular Disturbances in France and England, 1730-1848, Nueva York, Wiley \& Sons, 1964.

Sahlins, Marshall, Economía de la Edad de Piedra, Madrid, Akal, 1977.

Sahlins, Marshall, The Western Illusion of Human Nature. With reflections on the long history of hierarchy, equality, and the sublimation of anarchy in the West, and comparative notes on other conceptions of the human condition, Chicago, Prickly Paradigm Press, 2008.

Sánchez Ferlosio, Rafael, "La música celestial de la verdad", Le Monde Diplomatique: número de Marzo, 1999, págs. 30-31.

Skocpol, Theda, States and Social Revolutions: A Comparative Analysis of France, Russia, and China, Nueva York, Cambridge University Press, 1979.

Smith, Adam, Lectures on Jurisprudence, Oxford University Press, 1978.

Spencer, Herbert, Principios de sociología, Madrid, Revista de Occidente, 1947.

Teilhard de Chardin, Pierre, La place de l'homme dans la nature. Le groupe zoologique humaine, Paris, Union Générale d'Editions, 1956. 
Thompson, Edward P., "La economía moral de la multitud en la Inglaterra del Siglo XVIII", Tradición, revuelta y conciencia de clase. Estudios sobre la crisis de la sociedad preindustrial, Barcelona, Crítica, 1979, págs. 62-134.

Thompson, Edward P., "Tiempo, disciplina de trabajo y capitalismo industrial”, Tradición, revuelta y conciencia de clase. Estudios sobre la crisis de la sociedad preindustrial, Barcelona, Crítica, 1979, págs. 239-293.

Tilly, Charles, Grandes estructuras, procesos amplios, comparaciones enormes, Madrid, Alianza, 1991.

Tönnies, Ferdinand, Comunidad y asociación. El comunismo y el socialismo como formas de vida social, Barcelona, Península, 1979.

Tomás de Aquino, Summa Teologiae, Madrid, Biblioteca de Autores Cristianos, 1917.

Tucidides, Historia de la Guerra del Peloponeso, Madrid, Gredos, 1992.

Turgot, A.R., Discursos sobre el progreso humano, Madrid, Tecnos, 1991.

Weber, Max, "Capitalismo y sociedad rural en Alemania", Ensayos de sociología contemporánea, II, Barcelona, Planeta, 1985, págs. 133-162.

Weber, Max, Economía y Sociedad. Esbozo de sociología comprensiva, México, Fondo de Cultura Económica, 1987.

Weber, Max, La ética protestante y el espíritu del capitalismo, Barcelona, Península, 1977.

Wolf, Eric, Los campesinos, Barcelona, Labor, 1982.

Worsley, Peter, Al son de la trompeta final. Un estudio de los cultos "cargo" en Melanesia, Madrid, Siglo XXI, 1980. 
